\title{
ANALISIS STRATEGI INOVASI DALAM MENINGKATKAN VOLUME PENJUALAN PRODUK OLAHAN DAUN KELOR PADA CV. KREATIF MARONGGIH CENTER COMMUNITY
}

\author{
SITI HUSNUL HOTIMA* \\ SUFA'ATI \\ Program Studi Ilmu Administrasi Niaga \\ Sekolah Tinggi Ilmu Administrasi Pembangunan Jember \\ *Email: husnul@stiapembangunanjember.ac.id
}

\begin{abstract}
ABSTRAK
Upaya pencapaian peningkatan penjualan dapat dilakukan dengan strategi inovasi. Dengan melakukan inovasi, perusahaan berharap bisa selalu menciptakan hal-hal yang baru dari pada sebelumnya Strategi inovasi produk dengan tiga indikator yang terdiri dari fitur, desain dan kualitas secara logika dapat dipastikan akan meningkatkan volume penjualan. Peningkatan volume penjualan dipengaruhi oleh beberapa faktor yang antara lain adalah kualitas barang, selera konsumen, servis pelanggan dan persaingan harga jual. Dengan menggunakan Teknik analisis SWOT, matriks IFAS, matriks EFAS, matriks BCG, dan matriks Grand Strategi.. Penelitian ini menggunakan metode kualitatif, yaitu studi kasus yang menghasilkan data-data deskriptif yang dituangkan dalam kata-kata. kegiatan usaha dari CV.KM-2C dalam kondisi yang aktif bergerak untuk memotivasi di segala segi serta demi peningkatan produktifitas yang didukung dengan peningkatan penjualan untuk mencapai peningkatan yang optimal atas perolehan keuntungan usaha.

Kekuatan usaha yang masih dalam kisaran kekuatan medium pertengahan sebesar 1,40 mempunyai peluang yang lebih besar yaitu sebesar 1,59. Hal ini mengakibatkan usaha dalam kondisi Comparative Advantage pada tingkat 2,93. Artinya usaha harus aktif melakukan pengembangan dan inovasi secara kumulatif untuk meraih peluang yang begitu bagus.
\end{abstract}

Kata Kunci: Strategi, Inovasi, Produk, Analisis SWOT 


\section{PENDAHULUAN}

Upaya pencapaian peningkatan penjualan dapat dilakukan dengan strategi inovasi. Dengan melakukan inovasi perusahaan berharap bisa selalu menciptakan hal-hal yang baru dari pada sebelumnya. Melalui inovasi produk, pimpinan perusahaan dapat mengatasi permasalahan bisnis. Hal tersebut menjadi dasar dalam meningkatkan kelangsungan hidup dan mencapai kesuksesan perusahaan dalam jangka panjang. Inovasi merupakan proses menciptakan nilai yang dimotori oleh kemampuan untuk melihat hubungan, peluang dan kemudian mengambil keuntungan dari hal tersebut (Burgelman,et.al,1990). Inovasi mencakup kreatifitas dalam menciptakan produk baru, jasa, ide atau proses baru. Dengan perkataan lain, inovasi bisa diartikan sebagai proses adaptasi produk, jasa, ide, atau proses baik yang sudah ada dalam organisasi maupun yang dikembangkan dari luar organisasi.

CV. KM-2C (Kreatif Maronggih Center Community) mendirikan usaha agro industri tanaman kelor di desa Kesilir Kecamatan Wuluhan
Kabupaten Jember. Perusahaan ini yang dipimpin oleh Bapak Imam Syafi'i. Usaha ini mengolah daun kelor segar menjadi aneka produk dengan merek "Kelir" (Kelor Kesilir). Daun kelor ini telah diinovasi dengan berbagai macam bentuk dan kemasan. Produk daun kelor ini, digunakan sebagai obat herbal, produk kecantikan, untuk campuran makanan olahan, dan minuman, serta untuk campuran pakan ternak (sentrat). Berikut aneka jenis produk Kelor.

Tabel 1. Jenis dan Harga Produk

\begin{tabular}{|c|c|c|}
\hline \multicolumn{3}{|c|}{ Kelir } \\
\hline No. & $\begin{array}{l}\text { Nama } \\
\text { Produk }\end{array}$ & $\begin{array}{l}\text { Harga / } \\
\text { Satuan }\end{array}$ \\
\hline 1. & $\begin{array}{l}\text { Serbuk daun } \\
\text { kelor }\end{array}$ & $\begin{array}{l}\text { Rp } \\
30.000 / \\
\text { ons }\end{array}$ \\
\hline 2. & $\begin{array}{l}\text { Teh celup } \\
\text { kelor }\end{array}$ & $\begin{array}{l}\text { Rp } \\
10.000 / \\
\text { sachet }\end{array}$ \\
\hline 3. & $\begin{array}{l}\text { Daun kelor } \\
\text { kering }\end{array}$ & $\begin{array}{l}\mathrm{Rp} \\
20.000 / \\
\mathrm{Kg}\end{array}$ \\
\hline
\end{tabular}

Sumber Data: CV. KM-2C

Guna menunjang keberlangsungan usaha agroindustri, khususnya untuk menunjang ketersediaan bahan baku berupa daun kelor, CV.KM-2C bekerja sama dengan petani binaan $\mathrm{CV}$. KM-2C. 
Kebun kelor yang diolah para petani binaan CV. KM-2C yaitu di desa Jati gowok, desa Taman sari, dan desa Andongsari dengan total lahan seluas 2,5 hektar. CV. KM-2C berada pada tiga tempat antara lain di desa Kesilir sebagai kantor dan tempat produksi, di desa Taman sari sebagai tempat proses pengeringan (green house) beserta kebun kelor, dan di desa Andongsari adalah kebun kelor saja.

- Sementara penetapan target penjualan di lima tahun mendatang sejumlah 100 kilogram serbuk daun kelor per bulan dengan peningkatan secara berangsur. Penentuan target penjualan pada tahun 2018 dengan total $550 \mathrm{~kg}$ dengan prosentase

Tabel 2. Perubahan Harga Produk Serbuk Kelor

\begin{tabular}{|c|c|c|c|c|}
\hline \multirow{2}{*}{ Keterangan } & \multicolumn{2}{|c|}{2018} & \multicolumn{2}{|c|}{2019} \\
\hline & Plastik/kg & Alminiun/ons & Plastik/kg & Alminiun/ons \\
\hline $\begin{array}{c}\text { Jual } \\
\text { Peningkatan }\end{array}$ & Rp160.000 & $\operatorname{Rp} 25.000$ & $\begin{array}{c}\text { Rp192.000 } \\
20 \%\end{array}$ & $\begin{array}{c}\text { Rp30.000 } \\
20 \%\end{array}$ \\
\hline $\begin{array}{c}\text { Produksi } \\
\text { Peningkatan }\end{array}$ & Rp145.200 & Rp14.520 & $\begin{array}{c}\text { Rp173.200 } \\
19 \%\end{array}$ & $\begin{array}{c}\text { Rp17.320 } \\
19 \%\end{array}$ \\
\hline $\begin{array}{c}\text { Kemasan } \\
\text { Peningkatan }\end{array}$ & $\operatorname{Rp} 300$ & $\operatorname{Rp} 8.100$ & $\begin{array}{c}\text { Rp } 300 \\
0 \%\end{array}$ & $\begin{array}{c}\text { Rp } 9.400 \\
16 \%\end{array}$ \\
\hline $\begin{array}{l}\text { Tarif Produk } \\
\text { Peningkatan }\end{array}$ & Rp145.500 & Rp22.620 & $\begin{array}{c}\text { Rp173.500 } \\
19 \%\end{array}$ & $\begin{array}{c}\text { Rp26.720 } \\
18 \%\end{array}$ \\
\hline $\begin{array}{c}\text { Laba } \\
\text { Peningkatan }\end{array}$ & Rp14.500 & Rp2.380 & $\begin{array}{c}\text { Rp18.500 } \\
28 \%\end{array}$ & $\begin{array}{c}\text { Rp3.280 } \\
38 \%\end{array}$ \\
\hline$\%$ Laba & $10 \%$ & $11 \%$ & $11 \%$ & $12 \%$ \\
\hline
\end{tabular}

Sumber : CV. KM-2C
100\%, tahun 2019 dengan total $600 \%$ dengan prosentase 109\%, tahun 2020 dengan total $660 \mathrm{~kg}$ dengan prosentase $110 \%$, tahun 2021 dengan total $780 \mathrm{~kg}$ dengan prosentase $118 \%$, tahun 2022 dengan total $960 \mathrm{~kg}$ dengan prosentase $123 \%$, tahun 2023 dengan total $1200 \mathrm{~kg}$ dengan prosentase $125 \%$.

Dengan peningkatan target penjualan per tahun yang selalu berangsur meningkat maka ada peningkatan di semua harga. Baik itu harga jual, harga produksi, bahkan harga kemasan juga perolehan laba. Hal ini nampak pada tabel berikut: 
Operasional produksi perusahaan dengan jumlah atas dasar pesanan. Hal ini dikarenakan kapasitas mesin masih dalam kisaran jumlah produksi untuk memenuhi kebutuhan menutup pesanan. Memang ada kelebihan yang relatif sedikit yang dijual secara retail atau eceran. Produk yang dijual secara retail ini dikemas dengan aluminium. Adapun perbandingan jumlah penjualan adalah penjualan pesanan dengan kemasan plastik dibandingkan dengan penjualan retail dengan kemasan aluminium sama dengan $19: 1$.

Kapasitas hasil produksi maximal adalah $4 \mathrm{~kg}$ x $25=100 \mathrm{~kg}$ per bulan. Peningkatan produksi dapat dilakukan dengan penambahan mesin produksi. Kondisi ini masih dalam proses pengumpulan laba untuk digunakan pengadaan mesin baru. Sementara peningkatan penjualan masih dalam proses pengenalan produk. Sehingga penjualan masih atas dasar pesanan. Dan selebihnya masih dalam upaya promosi pengenalan produk. Untuk itu perusahaan memberikan target selama lima tahun kedepan dengan penjualan dua kali lipat dari tahun 2019 ini yaitu $100 \mathrm{~kg}$ per bulan.

Lima tahun kedepan dengan perolehan laba ditahan sebesar Rp110.919.717,- maka pastilah CV. KM-2C sudah siap dengan operasional strategi yaitu tentang strategi produksi dan strategi penjualan. Dengan dana perolehan laba ditahan pastilah CV. KM-2C dapat mengembangkan usahanya dengan menambah investasi berupa mesin produksi serta penambahan modal kerja.

Untuk dapatnya mencapai target yang telah ditetapkan itulah permasalahan yang menjadi fenomena dan akan dijadikan kajian ilmiah tentang strategi inovasi produk pada CV. KM-2C di Kecamatan Wuluhan Kabupaten Jember. Dalam hal ini penulis mengkaji tentang strategi produksi yaitu dalam hal strategi inovasi produk. Dengan menggunakan analisa SWOT penulis berharap bisa mengetahui bagaimana strategi yang dilaksanakan perusahaan dalam meningkatkan volume penjualan produk kelir. 


\section{TINJAUAN PUSTAKA}

\subsection{Manajemen Strategi}

Manajemen strategi menurut Pearce \& Robinson (2016:3), merupakan suatu rangkaian keputusan dan tindakan yang menghasilkan formulasi dengan mengimplementasikan rencana untuk mencapai tujuan perusahaan. Manajemen strategi terdiri atas sembilan tugas penting antara lain:

a. Merumuskan misi perusahaan, termasuk pernyataan umum mengenahi intensi, falsafah dan tujuan perusahaan.

b. Melakukan analisis yang mencerminkan kondisi internal dan kemampuan perusahaan.

c. Menilai kondisi eksternal perusahaan, termasuk pesaing dan faktor-faktor konstektual umum.

d. Menganalisis pilihan-pilihan yang dimiliki perusahaan dengan menyesuaikan sumber daya yang dimiiki dengan lingkungan eksternal. e. Mengidentifikasi pilihan yang paling diinginkan dengan mengevaluasi setiap pilihan yang ada sesuai dengan misi perusahaan.

f. Memilih rangkaian tujuan jangka panjang dan strategi utama yang dapat menghasilkan pilihan yang paling diinginkan.

g. Merancang tujuan-tujuan tahunan dan strategi jangka pendek yang sesuai dengan rangkaian tujuan jangka panjang dan strategi utama yang telah dipilih.

h. Mengimplementasikan pilihan strategi sesuai dengan anggaran alokasi sumberdaya yakni, menyeseuaikan tugas-tugas yang akan dilaksanakan para pelaksana, struktur, teknologi, dan sistem penghargaan merupakan hal yang ditekankan.

i. Mengevaluasi keberhasilan proses strategis sebagai bahan masukkan untuk 
pengambilan keputusan pada masa yang akan datang.

\subsection{Manajemen Inovasi}

Dhewanto dkk (2015:108) dalam buku menejemen inovasi untuk usaha kecil dan mikro, banyak hal yang berkaitan dengan inovasi produk. Penulis buku "Principles of Marketing" Kotler dan Armstrong (2010) menyebutkan bahawa terdapat tiga indikator inovasi produk yaitu: fitur produk, desain dan rancangan produk dan yang terakhir kualitas produk.

a. Fitur produk

Varian produk dapat dianggap sebagai sebuah sarana yang kompetitif dan pembeda antara produk yang diciptakan oleh sebuah perusahaan dengan produk pesaingnya.Fitur dari sebuah produk merupakan modal sebuah produk agar dapat bersaing untuk memenangkan perhatian konsumen. Yang dimaksud fitur dari sebuah produk adalah sesuatu yang unik, istimewa dan kekhasan yang dimiliki produk tersebut sebagai nilai jual tambahan.
Karakteristik yang melekat dengan sempurna pada sebuah produk merupakan hasil dari pengembangan dan penyempurnaan secara terus menerus.

b. Desain dan rancangan produk

Desain produk merupakan cara yang lain untuk mendapatkan nilai tambah produk dimata penggunanya. Desain adalah cara atau konsep yang mampu mewakili dan menggambarkan sebuah produk. Desain tidak hanya memiliki kontribusi terhadap ketrampilan namun juga terhadap kegunaan produk. Suatu produk didesain dengan tujuan agar dapat menarik perhatian konsumen, dapat pula sebagai sebuah strategi untuk memotong biaya produksi, desain juga dapat memberikan keunggulan bersaing. Kotler dan Armstrong (2010) menyatakan bahwa desain atau rancangan produk sebagai sebuah keistimewaan yang dapat mempengaruhi bukan hanya penampilan namun 
juga fungsi produk dari segi kebutuhan konsumen.

c. Kualitas produk

Kualitas produk merupakan sebuah tingkatan dari produk yang mampu melakukan fungsifungsinya semaksimal mungkin. Fungsi yang dimaksud diantaranya adalah daya tahan produk, kehandalan dan ketelitian dari produk yang dihasilkan oleh sebuah perusahaan. Disisi lain kehandalan merupakan produk yang terbebas dari kecacatan, memiliki kesesuaian kinerja dan konsistensi kemampuan yang sesuai dengan fungsinya. Menjaga kualitas produk sangat bermanfaat bukan hanya untuk membangun kepercayaan konsumen yang sudah dimiliki sebelumnya. Namun demikian, permasalahan yang sering terjadi didalam bisnis terjadi ketika sebuah produk yang memiliki kualitas yang baik dan bagus, tapi harga yang ditawarkan sangat mahal.

\subsection{Volume Penjualan}

Volume penjualan menurut Freddy Rangkuti (2009:207) bahwa volume penjualan adalah pencapaian yang dinyatakan secara kuantitatif dari segi fisik atau volume atau unit suatu produk. Volume penjualan merupakan suatu yang menandakan naik turunnya penjualan dan dapat dinyatakan dalam bentuk unit, kilo, ton, atau liter.

Adapun faktor-faktor yang mempengaruhi volume penjualan antara lain:

a. Kualitas barang

Turunnya mutu barang dapat mempengaruhi volume penjualan, jika barang yang diperdagangkan mutunya menurun dapat menyebabkan pembelinya yang sudah jadi pelanggan dapat merasakan kecewa sehingga mereka bisa berpaling kepada barang lain yang mutunya lebih baik.

b. Selera konsumen

Selera konsumen tidaklah tetap dan ia dapat berubah setiap saat, bilamana selera konsumen terhadap barang-barang yang 
kita perjualkan berubah maka volume prnjualan akan menurun.

c. Servis terhadap pelanggan

Servis terhadap pelanggan merupakan faktor penting dalam usaha memperlancar penjualan terhadap usaha dimana tingkat persaingan semakin tajam.

d. Persaingan menurut harga jual

Potongan harga dapat diberikan dengan tujuan agar penjualan dan keuntungan perusahaan dapt ditingkatkan dari sebelumnya. Potonganharga tersebut dapat diberikan kepada pihak tertentu dengan syaratsyarat tertentu pula.

\subsection{Hubungan antara Strategi Inovasi Produk dengan Peningkatan Volume \\ Penjualan}

Strategi inovasi produk dengan tiga indikator yang terdiri dari fitur, desain dan kualitas secara logika dapat dipastikan akan meningkatkan volume penjualan. Apalagi peningkatan volume penjualan dipengaruhi oleh beberapa faktor yang antara lain adalah kualitas barang, selera konsumen, servis pelanggan dan persaingan harga jual. Dibawah ini secara teori dapat dibahas hubungan antara strategi inovasi produk dengan peningkatan volume penjualan sesuai faktor yang memengaruhinya. Hal ini dapat digambarkan sebagai berikut:

\section{Peningkat Volume Penjualan}

1. Kualitas barang

2. Selera konsumen

3. Servis terhadap pelanggan

4. Persaingan menurut harga jual

1. Fitur produk

2. Desain produk

3. Kualitas produk

Gambar 1. Hubungan antara Strategi Inovasi Produk dengan Peningkatan Volume Penjualan

\subsection{Kerangka Pemikiran}

Hubungan yang terjadi antara ketiga indikator strategi inovasi produk terhadap empat faktor yang dapat mempengaruhi peningkatan volume penjualan dapat dianalisa menggunakan analisa SWOT yaitu bagaimana kekuatan, kelemahan, peluang dan ancaman yang terjadi 
dengan adanya strategi inovasi produk tersebut.

\section{METODE PENELITIAN}

Penelitian ini merupakan jenis penelitian kualitatif dengan menggunakan pendekatan studi kasus (case study). Adapun yang membedakan penelitian dengan pendekatan studi kasus dengan jenis pendekatan penelitian kualitatif yang lain terdapat pada kedalaman analisisnya pada sebuah kasus tertentu yang lebih spesifik. Kasus yang dimaksud dalam penelitian ini adalah strategi inovasi produk yang dilakukan oleh CV. KM-2C.

Adapun para informan dalam penelitian ini adalah Pimpinan CV.
KM-2C, kepala bagian produksi, dan konsumen dari produk KELIR. Pada penelitian ini digunakan salah satu alat analisa yaitu metode SWOT (Strenght, Weakness, Opportunity, Threats). SWOT adalah suatu bentuk analisis didalam manajemen perusahaan atau dalam organisasi yang secara sistematis dapat membantu dalam usaha penyusunan suatu rencana yang matang untuk mencapai tujuan, baik tujuan jangka pendek maupun panjang.

\section{HASIL PENELITIAN DAN PEMBAHASAN}

\subsection{Hasil Wawancara}

Pedoman pertanyaan peneliti:
a. Bagaimana kekuatan, kelemahan, peluang dan ancaman dari fitur produk dalam kualitas produk, selera konsumen, sajian dan layanan konsumen, harga penjualan dalam hubungannya dengan penjualan produk?

b. Bagaimana kekuatan, kelemahan, peluang dan ancaman dari desain produk dalam kualitas produk, selera konsumen, sajian dan layanan konsumen, harga penjualan dalam hubungannya dengan penjualan produk? kelemahan, peluang dan 
ancaman dari kualitas mengidentifikasi berbagai faktor produk dalam kualitas secara sistimatis untuk merumuskan produk, selera konsumen, strategi dalam meningkatkan tingkat sajian dan layanan volume penjualan produk sebuah konsumen, harga penjualan dalam hubungannya dengan penjualan produk?

perusahaan. Analisis ini didasarkan pada logika yang dapat memaksimalkan kekuatan (strength) dan peluang (oppurtunities), namun

\subsection{Analisis SWOT} secara bersamaan dapat

Analisis SWOT adalah alat meminimalisir kelemahan teknik penelitian kualitatif untuk (weakness), dan ancaman (threat).

1. Pembentukan Matrik IFAS dan Matrik EFAS

Tabel 3. Matrik IFAS (Internal Factor Analysis Summary)

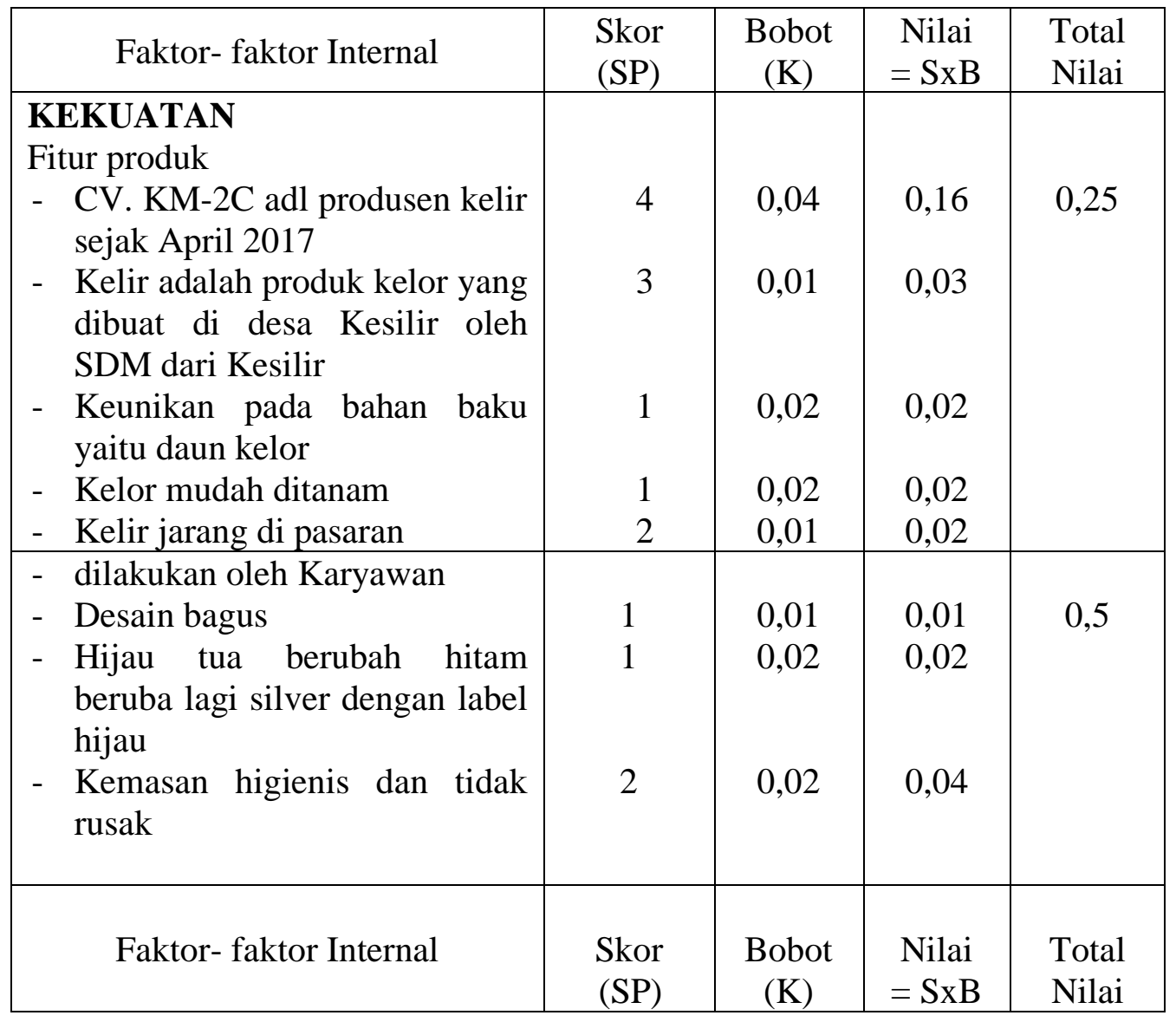




\begin{tabular}{|c|c|c|c|c|}
\hline Faktor- faktor Internal & $\begin{array}{l}\text { Skor } \\
\text { (SP) }\end{array}$ & $\begin{array}{c}\text { Bobot } \\
(\mathrm{K})\end{array}$ & $\begin{array}{c}\text { Nilai } \\
=\mathrm{SxB}\end{array}$ & $\begin{array}{l}\text { Total } \\
\text { Nilai }\end{array}$ \\
\hline $\begin{array}{l}\text { Kualitas produk } \\
\text { - } \text { Sesuai standar hieginis } \\
\text { - } \text { Punya sertifikat halal } \\
\text { - } \text { Dapat dikonsumsi bagi bayi, } \\
\text { balita, usia dewasa } \\
\text { - } \text { Produk baru sehingga kualitas } \\
\text { terjamin } \\
\text { - } \text { Bahan baku berupa daun segar } \\
\text { dan muda } \\
\text { - Kualitas sangat terjamin. } \\
\text { - Kelir berguna untuk produk } \\
\text { turunan. } \\
\text { - Kelir tidak cacat produk }\end{array}$ & $\begin{array}{l}1 \\
1 \\
1 \\
2 \\
4 \\
4\end{array}$ & $\begin{array}{l}0,02 \\
0,04 \\
0,04 \\
0,01 \\
0,01 \\
0,02 \\
0,04 \\
0,04\end{array}$ & $\begin{array}{l}0,04 \\
0,16 \\
0,16 \\
0,01 \\
0,01 \\
0,04 \\
0,08 \\
0,16\end{array}$ & 0,65 \\
\hline Jumlah Nilai Kekuatan & 51 & 0,50 & 1,40 & 1,40 \\
\hline $\begin{array}{l}\text { KELEMAHAN } \\
\text { Fitur Produk } \\
\text { - Belum dikenal oleh masyarakat } \\
\text { umum } \\
\text { - Produk sisa dikemas dalam } \\
\text { aluminium foil sehingga biaya } \\
\text { packing bessar } \\
\text { - harus dipasarkan secara retail } \\
\text { maka perlu tenaga pemasaran }\end{array}$ & $\begin{array}{l}1 \\
3\end{array}$ & $\begin{array}{l}0,05 \\
0,05 \\
0,03\end{array}$ & $\begin{array}{l}0,05 \\
0,15 \\
0,06\end{array}$ & 0,26 \\
\hline $\begin{array}{l}\text { Desain Produk } \\
\text { - Tidak ada kemasan sekali pakai } \\
\text { - Masih dalam perbaikan Gedung } \\
\text { - Masih dalam upaya pemilikan } \\
\text { mesin baru untuk menambah } \\
\text { kapasitas produksi }\end{array}$ & $\begin{array}{l}2 \\
4 \\
\end{array}$ & $\begin{array}{l}0,01 \\
0,03 \\
0,06\end{array}$ & $\begin{array}{l}0,01 \\
0,06 \\
0,24\end{array}$ & 0,31 \\
\hline $\begin{array}{l}\text { Kualitas Produk } \\
\text { - Mesin produksi atas Hibah UB } \\
\text { yang berstandar BPOM dengan } \\
\text { kapasitas masih terbatas" } \\
\text { - Priodikal produkbelum } \\
\text { diketahui } \\
\text { - Bangunan masih } 80 \% \text { permanen } \\
\text { sehingga belum bebas dalam } \\
\text { memasarkan produk } \\
\text { - lokasi proses tidak berdekatan } \\
\text { - Kelemahan masih berupaya } \\
\text { untuk pendekatan agar lebih } \\
\text { efektif }\end{array}$ & $\begin{array}{l}4 \\
2\end{array}$ & $\begin{array}{l}0,06 \\
0,04\end{array}$ & $\begin{array}{l}0,15 \\
0,24 \\
0,08\end{array}$ & \\
\hline
\end{tabular}




\begin{tabular}{|c|c|c|c|c|}
\hline Faktor- faktor Internal & $\begin{array}{c}\text { Skor } \\
(\mathrm{SP})\end{array}$ & $\begin{array}{c}\text { Bobot } \\
(\mathrm{K})\end{array}$ & $\begin{array}{c}\text { Nilai } \\
=\mathrm{SxB}\end{array}$ & $\begin{array}{c}\text { Total } \\
\text { Nilai }\end{array}$ \\
\hline $\begin{array}{l}\text { - Bekerja bersama untuk } \\
\text { kesejahteraan bersama }\end{array}$ & 1 & 0,02 & 0,02 & 0,81 \\
\hline Total Nilai Kelemahan & 29 & 0,50 & 1,38 & 1,38 \\
\hline Jumlah Nilai IFAS & 80 & 1,00 & 2,78 & 2,78 \\
\hline
\end{tabular}

Sumber data: Data diolah

Berdasarkan tabel IFAS sedangkan faktor kelemahan

(Internal Factor Analysis Summary)

(Weakness) sebesar 1,38 sehingga

diatas menunjukkan bahwa Tingkat IFAS sebesar 2,78.

Kekuatan (Strength) sebesar 1,40

Tabel 4. Matrik EFAS (External Factor Analysis Summary)

\begin{tabular}{|c|c|c|c|c|}
\hline Faktor-faktor Internal & $\begin{array}{l}\text { Skor } \\
\text { (SP) }\end{array}$ & $\begin{array}{c}\text { Bobot } \\
(\mathrm{K})\end{array}$ & $\begin{array}{l}\text { Nilai } \\
=\mathrm{SxB}\end{array}$ & $\begin{array}{l}\text { Total } \\
\text { Nilai }\end{array}$ \\
\hline \multicolumn{5}{|l|}{ PELUANG } \\
\hline $\begin{array}{l}\text { Fitur Produk } \\
\text { - } \text { Kelor mudah tumbuh } \\
\text { - } \text { Banyak dimiliki oleh masyarakat } \\
\text { - } \text { Kelor bebas hama } \\
\text { - } \quad \text { Luas lahan Kelor } 2,5 \mathrm{Ha} \\
\text { - } \\
\text { - }\end{array}$ & $\begin{array}{l}4 \\
3 \\
3 \\
4 \\
2 \\
4\end{array}$ & $\begin{array}{l}0,03 \\
0,02 \\
0,02 \\
0,03 \\
0,02 \\
0,03\end{array}$ & $\begin{array}{l}0,12 \\
0,06 \\
0,06 \\
0,12 \\
0,04 \\
0,12\end{array}$ & 0,52 \\
\hline $\begin{array}{l}\text { Desain Dan Rancangan Produk } \\
\text { - } \quad \text { Serbuk kelor dapat digunakan produk } \\
\text { turunan berupa Food \& Feed } \\
\text { - } \text { Karena dikenal maka dapat menjual } \\
\text { - } \text { Kelebihan produksi dijual eceran } \\
\text { - } \text { Produk lain berupa teh celup kelor dan } \\
\text { daun kelor kering } \\
\text { - } \text { Inovasi dalam lokasi dan mesin produksi } \\
\text { akan meningkatkan produktifitas serta } \\
\text { kualitas semakin sempurna baik } \\
\text { - } \quad \text { kualitas yang dapat dikonsumsi siapapun } \\
\text { - } \text { Kemasan dengan specifik } \\
\text { - } \text { Brosur sebagai alat promosi } \\
\text { - } \text { Produk baru berbentuk capsul } \\
\text { - Desain bagus, Hijau tua berubah hitam } \\
\text { berubah lagi silver dengan label hijau } \\
\text { - Kemasan higienis dan tidak rusak }\end{array}$ & $\begin{array}{l}4 \\
3 \\
2 \\
3 \\
4\end{array}$ & $\begin{array}{l}0,03 \\
0,02 \\
0,01 \\
0,02 \\
0,03\end{array}$ & $\begin{array}{l}0,12 \\
0,06 \\
0,02 \\
0,06 \\
0,12\end{array}$ & 0,66 \\
\hline \multicolumn{5}{|l|}{ Lanjutan: } \\
\hline Faktor-faktor Internal & Skor & Bobot & Nilai & Total \\
\hline
\end{tabular}




\begin{tabular}{|c|c|c|c|c|}
\hline Faktor-faktor Internal & $\begin{array}{l}\text { Skor } \\
\text { (SP) }\end{array}$ & $\begin{array}{c}\text { Bobot } \\
(\mathrm{K})\end{array}$ & $\begin{aligned} & \text { Nilai } \\
= & \mathrm{SxB}\end{aligned}$ & $\begin{array}{l}\text { Total } \\
\text { Nilai }\end{array}$ \\
\hline & $(\mathrm{SP})$ & $(\mathrm{K})$ & $=\mathrm{SxB}$ & Nilai \\
\hline Kualitas produk & 1 & 0,01 & 0,01 & 0,41 \\
\hline - Kelebihan permintaan & 4 & 0,04 & 0,16 & \\
\hline $\begin{array}{l}\text { - The right man and the right place akan } \\
\text { sangat berproduktif }\end{array}$ & 4 & 0,03 & 0,12 & \\
\hline $\begin{array}{l}\text { - Bila BPOM turun maka kelir dijual pada } \\
\text { apotik, toko obat dan supermarket }\end{array}$ & 2 & 0,01 & 0,02 & \\
\hline $\begin{array}{l}\text { - Berguna bagi kesehatan, pengobatan, } \\
\text { kecantikan }\end{array}$ & 3 & 0,03 & 0,09 & \\
\hline $\begin{array}{l}\text { - Penelitian kandungan nutrisi dan nilai } \\
\text { gizi bersama UB dan Unej } \\
\text { - Kelir tidak cacat produk }\end{array}$ & 1 & 0,01 & 0,01 & \\
\hline Total Peluang (Opportunity) & 64 & 0,50 & 1,59 & 1,59 \\
\hline \multicolumn{5}{|l|}{ KELEMAHAN } \\
\hline $\begin{array}{l}\text { Fitur Produk } \\
\text { - } \quad \text { Masyarakat pemilik paham akan } \\
\quad \text { memproses sendiri secara manual }\end{array}$ & 4 & 0,10 & 0,40 & 0,40 \\
\hline $\begin{array}{ll} & \text { Desain Dan Rancangan Produk } \\
\text { - } & \text { Simple akan mudah ditiru } \\
\text { - } & \text { Kapasitas produksi masih endah }\end{array}$ & $\begin{array}{l}4 \\
4\end{array}$ & $\begin{array}{l}0,10 \\
0,10\end{array}$ & $\begin{array}{l}0,40 \\
0,40\end{array}$ & 0,80 \\
\hline $\begin{array}{l}\text { Kualitas Produk } \\
\text { - } \\
\text { Perlu biaya untuk pelatihan } \\
\text { persaingan pangsa pasar, kualitas } \\
\text { produk, dan harga jual cukup kompetitif. } \\
\text { Masyarakat pengguna secara natural }\end{array}$ & $\begin{array}{l}2 \\
3\end{array}$ & $\begin{array}{l}0,05 \\
0,05\end{array}$ & $\begin{array}{l}0,10 \\
0,15 \\
0,10\end{array}$ & 0,35 \\
\hline Total Kelemahan (Treath) & 20 & 0,50 & 1,55 & 1,55 \\
\hline Total EFAS & 84 & 1,00 & 3,14 & 3,14 \\
\hline
\end{tabular}

Sumber data: Data diolah

Berdasarkan tabel EFAS

(External Factor Analysis Summary)

diatas menunjukkan bahwa Tingkat

Peluang (Opportunity) sebesar 1,59

sedangkan faktor Ancaman (Treath)

sebesar 1,55 sehingga EFAS sebesar 3,14 .
2. Pembentukan Wilayah Aktifitas

Usaha Dengan Matrix BCG

Dalam pembentukan wilayah aktifitas usaha dapat ditunjukkan adanya posisi dimana faktor internal yang mempengaruhi kegiatan usaha serta faktor eksternal yang mengakibatkan termotivasinya kegiatan internal usaha. 
Tabel 5. Matrik BCG

\begin{tabular}{|c|c|c|}
\hline EFAS $=3,14$ & Treats $(\mathrm{T})=1,55$ & Opportunity $(\mathrm{O})=1,59$ \\
\hline IFAS $=2,78$ & $\begin{array}{c}\mathrm{ST}=2,95 \\
\text { Mobilization }\end{array}$ & $\begin{array}{c}\mathrm{ST}=2,99 \\
\text { Comparative Advatage }\end{array}$ \\
\hline Strength $(\mathrm{S})=1,40$ & $\begin{array}{c}\mathrm{WT}=2,93 \\
\text { Damage Control }\end{array}$ & $\begin{array}{c}\mathrm{WO}=2,97 \\
\text { Divestment } / \text { Investment }\end{array}$ \\
\hline
\end{tabular}

Sumber data: Data diolah

3. Pembentukan Posisi Kompetitif

Kegiatan Usaha

Dalam pembentukan Posisi

Kompetitif Kegiatan usaha dapat ditunjukkan adanya posisi dimana faktor internal yang mempengaruhi kegiatan usaha serta faktor eksternal yang mengakibatkan termotivasinya kegiatan internal usaha.

Tabel 6. Matrik Posisi Kompetitif Kegiatan Usaha dengan Matrik Internal-

\begin{tabular}{|c|c|c|c|c|}
\hline \multicolumn{5}{|c|}{ Eksternal } \\
\hline \multirow{3}{*}{$\begin{array}{l}\quad \mathbf{4} \\
\mathbf{S}^{2} \\
\mathbf{A} \\
2,78 \\
\text { F } 2 \\
\text { I }\end{array}$} & \multirow[b]{2}{*}{ SPEKULATIF } & \multicolumn{3}{|c|}{ IDEAL } \\
\hline & & \multicolumn{3}{|c|}{$(3,14 ; 2,78)$} \\
\hline & GAWAT & \multicolumn{3}{|c|}{ DEWASA } \\
\hline $\mathbf{0}$ & \multicolumn{3}{|c|}{2} & 3,144 \\
\hline & $\mathbf{E}$ & $\mathbf{A}$ & $\mathbf{S}$ & \\
\hline
\end{tabular}

Sumber data: Data diolah

Dari Tabel diatas menunjukkan bahwa kegiatan usaha CV. KM-2C dalam posisi Ideal. Artinya kegiatan usaha dalam kualitas ideal, yaitu mempunyai posisi lagi naik daun. Maksudnya adalah kegiatan usaha sudah mencapai batas optimum dan sekarang masih dalam proses pengembangan.

Pada proses pengembangan ini apabila tidak terdetaksi maka akan terjadi penurunan. Sedangkan apabila permasalahan cepat terdeteksi dan segera mencari solusi 
maka kegiatan usaha akan semakin berkembang.
4. Hasil analisis Matrik SWOT

Pada hasil analisis SWOT maka dapat ditentukan adanya wilayah strategi kegiatan usaha CV. KM-2C. Hal ini dapat digambarkan sesuai dengan tabel dibawah ini.

Tabel 7. Matrik Grand Strategi

\begin{tabular}{|c|c|c|c|}
\hline 4 & $\begin{array}{c}\text { S }=\text { Strengths } \\
\text { Kekuatan Internal } \\
\text { Substansial }\end{array}$ & & \\
\hline $\begin{array}{c}\text { Sel-2 = ST } \\
\text { Mobilization } \\
\text { Posisi Spek-ulatif } \\
\text { rategi Difersifikas }\end{array}$ & \multicolumn{3}{|c|}{$\begin{array}{c}\text { Sel-1 = SO } \\
\text { Comparative Advantage } \\
\text { Posisi Ideal } \\
\text { Strategi Agresif }\end{array}$} \\
\hline $\begin{array}{l}\text { T }=\text { Threats } \\
\text { Ancaman Utama dari } \\
\text { Lingkungan External }\end{array}$ & \multicolumn{3}{|c|}{$\begin{array}{c}O=\text { Opportunities } \\
\text { Peluang Utama } \\
\text { Lingkungan External }\end{array}$} \\
\hline $\begin{array}{c}\text { Sel-4 = WT } \\
\text { Damage Control } \\
\text { Posisi Gawat } \\
\text { Strategi Defensif }\end{array}$ & \multicolumn{3}{|c|}{$\begin{array}{c}\text { Sel-3 = WO } \\
\text { Divestment/ Investment } \\
\text { Posisi Dewasa } \\
\text { Strategi Orientasi Putar Balik }\end{array}$} \\
\hline & $\begin{array}{l}\text { Ineses } \\
\text { al }\end{array}$ & 3,144 & \\
\hline
\end{tabular}

Sumber: Rangkuti (2014)

\section{KESIMPULAN DAN SARAN}

\subsection{Kesimpulan}

CV. KM-2C merupakan Salah satu perusahaan yang baru berkembang di kecamatan Wuluhan mempunyai Strategi Agresif dengan mendukung posisi ideal dalam usaha comparative advantage. Maksudnya adalah kegiatan usaha dari CV.KM-2C dalam kondisi yang aktif bergerak untuk memotivasi di segala segi serta demi peningkatan produktifitas yang didukung dengan peningkatan penjualan untuk mencapai peningkatan yang optimal atas perolehan keuntungan usaha. 
Posisi Ideal, artinya kegiatan usaha dalam kualitas ideal, yaitu mempunyai posisi lagi naik daun. Maksudnya adalah kegiatan usaha sudah mencapai batas optimum dan sekarang masih dalam proses pengembangan. Pada proses pengembangan ini apabila tidak terdetaksi maka akan terjadi penurunan. Sedangkan apabila permasalahan cepat terdeteksi dan segera mencari solusi maka kegiatan usaha akan semakin berkembang.

Kekuatan usaha yang Comparative Advantage yaitu usaha yang masih dalam kisaran kekuatan medium pertengahan sebesar 1,40 mempunyai peluang yang lebih besar yaitu sebesar 1,59. Hal ini mengakibatkan usaha dalam kondisi Comparative Advantage pada

\section{DAFTAR PUSTAKA}

Arikunto, 1996, Prosedur Penelitian, Rineka Cipta, Jakarta.

Alimiyah dan Padji, 2003. Kamus Istilah Akuntansi. Bandung: Yrama Widya.

Basrowi dan Suwandi, Memahami Penelitian Kualitatif, (Jakarta:Rineka Cipta, 2008), h. 28 tingkat 2,93. Artinya usaha harus aktif melakukan pengembangan dan inovasi secara kumulatif untuk meraih peluang yang begitu bagus.

\subsection{Saran}

Berdasarkan pengamatan penulis mengenai strategi inovasi produk yang diterapkan CV. KM-2C, maka saran yang ingin penulis sampaikan adalah:

1. Lebih Agresif dalam memotivasi kegiatan usaha.

2. Lebih mengarah ke pengembangan kegiatan usaha dalam mesinary, wilayah produksi dan pelatihan profesionalitas.

3. Lebih berinovasi untuk meraih peluang yang begitu besar tersedia.

Bulgerman, R.A., Christensen, C.M, \& Wheelwright, S.C (1990). StrategicManagement Technology and Innovation. McGraw Hill International Edition 5th Edition

Dhewanto, dkk.2015, Manejemen inovasi untuk usaha kecil dan mikro. Edisi Pertama. Bandung: Alfabeta 
Freddy Rangkuti, Analisis SWOT teknik membedah kasus bisnis, Jakarta:PT.Gramedia Pustaka Utama, 2008), hal. 19

Hendro,

Dasar-Dasar Kewirausahaan, (Jakarta: Erlangga, 2011), h.121.

Hof, Hamm DKK. Building an Idea Factory. Business Week, 11 Oktober 2014

Kotler,

Philip.1986. ManejemenPemasaran:Analisis ,Perencanaan,danpengendalian EdisiKelima.Jakarta:Erlangga

Kotler, Philip dan Armstrong, Garry, 2008. Prinsip-Prinsip Pemasaran Jilid 1.Erlangga Jakarta.

Krisnadi,2012. TheMultiple Distributer Of Moringa

Moleong, J, Lexy, 2011. Metodologi Penelitian Kualitatif. Bandung : PT Remaja Rosdakarya

Moleong, J, Lexy, 2016. Metodologi Penelitian Kualitatif. Bandung : PT Remaja Rosdakarya

Nasution.2002. Metode Research Penelitian Ilmiah Jakarta: PT Bumi Aksara

Oslo Manual, 2005. Guidelines For Colledge Coorperataion Innovation Data, OEDC Publishing

Pearce II , Robinson (2016) Manajemen Strategi, Formulasi, Implementasi dan Pengendalian Jakarta:Salemba Empat

Rangkuti, Freddy, 2009, Strategi Promosi Yang Kreatif, edisi pertama, cet. 1th, Gramedia pustaka Umum, Jakarta

Rangkuti, Freddy. 2014 Teknik Membedah Kasus Bisnis Analisis SWOT. Jakarta: PT Gramedia Pusaka Utama
Sedarmayanti, dan Hidayat, Syarifudin. 2011. Metodoligi Penelitian. Bandung: Mandar Maju.

Sugiyono, 2016. Memahami Penelitian Kualitatif. Bandung : Alfabeta

Schumpeter, J, A. (1934). The theory of economic development: an inquiry into profit, capital, credit, interest and the business cycle, Harvard University Press, Cambridge (Mass.)

Tedjo Tripomo dan Udan, Manajemen Strategi, Rekayasa Sains, Bandung, 2005, hal.118.

Trott, Paul Innovation Management and new Product Developmen, (2005)

Australia Institute for Commercialization. (2011). Innovation Tollbox.Diakses 27 Juni 2014, dari Innovation Toolbox. http://www.innovationtoolbox. com.au

Adrianah, Pengaruh Bauran Pemasarsn Terhadap Volume PejualanPada Pt. Ardan Masogi TBK Di Kota ParePare, Jurnal Ekonomix Volume 5 No. 1, Juni 2017

Christensen, Clayton M (1997), The Innovations Dilemma: When New Technologis Cause Great Firms To Fail Boston, Massashusetts, USA: Havard Business School Press, ISBN 978-0-87584-585-2

Nora Anisa Br Sinulingga, Pengaruh Strategi Pemasaran Terhadap Volume Penjualan pada PT. Citra Mandiri Lestari, Jurnal Mantik Penusa, olume 17 No 1, Juni 2015 
Makmur , Saprijal, Strategi Pemasaran Dalam Meningkatkan Volume Penjualan pada S-Mart Swalayan Pasir Pangaraian, Jurnal Ilmiah Cano Ekonomi Vol. 3 No. 1 Januari 2015

Oslo Manual, 2005. Guidelines For Colledge Coorperataion
Innovation Data, OEDC Publishing

Susilowati, Analisis Faktor-faktor Yang Mempengaruhi Volume Penjualan Feminimae Hydine Sirih Pada PT. Romos Inti Kosmetik, Surabaya.Jurnal Lentera, Vol 14, No.2 September 2016 